of liquids in viscometers, and exhibited viscometers designed to eliminate the surface tension difficulty.

On the subject of the measurement of viscosity of non-Newtonian liquids, Dr. K. Weissenberg mentioned the method of making the liquid system vibrate and observing the wave motion. The meeting discussed the use of the falling sphere method; Dr. E. Mardles pointed out that the rate of fall of a sphere through paints and greases varies considerably with depth, and often the sphere remains suspended, a finding confirmed by Dr. Barr, who with an unusual sample of tar and using X-ray photography found that the ball remained practically suspended before reaching the bottom. Dr. Mardles has obtained more promising results by using a thin plate drawn through the system, the rate of movement being nearly constant through the bulk. By varying the weight attached to the fine thread over a light pulley pulling the plate, it is possible to determine the yield value (see Nature, August 10, p. 199).

Those present visited departments where investigations of a rheological character were in progress; these included the silting of harbours, the slow creep of metals, the ventilation of buildings, plastics, use of strain gauges, etc.

\section{$|2|$ \\ UTILIZATION OF AFRICAN FOREST WOODS}

$\mathrm{W}$ AR production forms the main theme of the annual reppet of some of the African forest services-thos for nds for timber and wild rubber proguction, th latter due to the disappearance of the Malatin supplies. In the report for 1943 from Nilof (Govt. Printers, Lagos, 1944) it is stated that military demands for timber revived, while the projected relaying of the railway line between Jebba and Minna required over a period of three years 300,000 sleepers. It was hoped to supply a high proportion of these from the Kurmis of the northern provinces, from Khaya senegalensis and grandifoliola. Trouble was experienced from warping and cracking due to an exceptionally severe harmattan; an exacting specification impossible for pit-sawyers to fulfil and other difficulties were experieneed. These resulted in a high percentage of rejects, so the work of supplying is to be transferred to the southern provinces, although this involves long haulages by rail. Besides this railway contract, of which a portion was cut, $333,358 \mathrm{cu}$. ft. were produced for military use ; $1,455,730 \mathrm{cu}$. ft. for local consumption ; $40,924 \mathrm{cu}$. ft. from the mines, and $2,038,592 \mathrm{cu}$. ft. by logs and timber cut for export. This latter went to the United Kingdom, United States, South Africa, other parts of West Africa and French West Africa. One notable result of this increased war demand for timber, especially sawn timber required by the military, is the substantial and growing local demand by the African for this last type of material, which should, in the future, result in far better housing conditions for the population.

In the report for 1943-44 from the Gold Coast (Govt. Printing Department, Accra, 1944) timber and rubber production appear to have proved the chief preoccupations of the Department. Apart from the pit-sawn timber used locally, the pit-sawn timber supplies handled by the Department through its numerous subcontractors totalled 1,060,000 $\mathrm{cu}$. ft. This was supplied to the British Services, United States Army, Government Departments, etc. 133,000 pit-sawn sleepers required for an extension of the Gold Coast Railway and demanded at short notice were included in the above. One outcome of the military demand was the making of furniture in the Colony, a woodworkers' company having been started in Accra. Here again this may lead to the adoption of better types of furniture in the houses of the Africans in the future. In the Gold Coast, as in India and other parts of the Empire, the demand for tool handles was met by local production, and cutlass handles, and handles for felling axes, pick axes, shovels, hoes, rakes and all kinds of hammers were prepared from local woods; as also shingles for roofing.

The annual report for 1944 for Uganda (Government Printing Department, Uganda, 1945) says that the demand for timber for operational use by the military became more pressing and everything possible was done to increase output by opening up new areas and arranging for the circulation and extension of sawmills. The nine firms working exclusive licences operated twelve mills and produced 32,873 tons of $50 \mathrm{cu}$. ft. of sawn timber each. plus 746 tons of export logs. Eleven other firms with twelve mills turned out 7,541 tons of sawn timber, while pit-sawyers produced 3,835 tons. This timber came from the crown lands, crown forests and private forest (about one sixth only). 79 per cent of the total went to the military, $8 \frac{1}{2}$ per cent to the civil governments, and the balance to the public. Exports were 749 tons of logs and 39,148 tons of sawn timber, including 126,395 sleepers. The report gives interesting information on the wild rubber collection, which has absorbed a proportion of the staff of all the Departments. "The Wild Rubber section collected $25 \cdot 75$ tons of dry Funtumia rubber in Bunyoro and private enterprise 8.04 tons in the Mabira Forest, while in Buganda the Department bought $3 \cdot 13$ tons of vine rubber and private enterprise $2 \cdot 47$ tons. All possible Funtumia trees have been severely tapped twice in two years and are exhausted, so tapping was stopped at the end of the year."

It is to be hoped that all the Departments, now that war-time demands have ceased, will undertake a careful.inventory of their exploited forests, so as to bring to an end any further overfelling where such has occurred.

\section{$22 / 6$ \\ APPOINTMENTS VACANT}

APPLICATIONS are invited for the following appointments on or before the dates mentioned:

LECTURER IN FRUT AND VEgETABLES-The Principal, Midland Agriculturaj Cofege, Sutton Bonington, Loughborough (August 24) ASSISTA I I cetren IN CHEMITRY, preferably with qualification in Parpey ical Chemistry, in the Bradford Technical CollegeTh. $B_{\text {inet }}$ of Education, Town Hall, Bradford (August 24).

LDof ERER IN CHEMISTRY in the Croydon Polytechnic-The Eduction officer, Education Office, Katharine Street, Croydon (August 24).

LECTURERS (2) on MINING SUBJEcts at the Coalville Mining and Technical Institute- The Director of Education, County Offices, Grey Friars, Leicester (August 30).

ENTOMOLOGIST, ASSISTANT LECTURER Or LECTURER IN THE DEPART. MENT OF ZOOLOCY AND COMPARATIVE ANATOMY, and an ASSISTANT LECTURER IN EXPERIMENTAL ZOOLOGY - The Registrar, University College, Cathays Park, Cardiff (August 31).

INSTRUMENT MAKER FOR PHYSICS WORKSHOP-The Head of the Physics and Mathematics Department, Central Technical College, Suffolk Street, Birmingham 1 (August 31).

ASSISTANT LECTURER (man or wOMan) IN BIOLOGY in the Bradford Technical College-The Director of Education, Town Hall, Bradford (August 31). 